\title{
Thermoprotective Properties of the Venom of the Transcaucasian Vipera (Macrovipera Lebetina Obtusa Dyigubsky, 1832)
}

\author{
Topchiyeva Shafiga *, Babaev Elmar \\ National Academy of Sciences of Azerbaijan, Baku, Azerbaijan
}

Email address:

shafiga.topchiyeva@mail.ru (T. Shafiga)

*Corresponding author

\section{To cite this article:}

Topchiyeva Shafiga, Babaev Elmar. Thermoprotective Properties of the Venom of the Transcaucasian Vipera (Macrovipera Lebetina Obtusa Dyigubsky, 1832). International Journal of Ecotoxicology and Ecobiology. Vol. 2, No. 3, 2017, pp. 98-101. doi: 10.11648/j.ijee.20170203.11

Received: May 15, 2017; Accepted: June 20, 2017; Published: July 21, 2017

\begin{abstract}
The paper presents data on the study of the thermoprotective properties of the venom of the Transcaucasian Vipeta (Macrovipera lebetina obtuse) on 120 white mongrel mice subjected to thermal exposure $\left(30-50^{\circ} \mathrm{C}\right)$ for 30 minutes with the injection of zootoxin in doses $(2 \mathrm{mg} / \mathrm{kg}$ and $4 \mathrm{mg} / \mathrm{kg})$. It was found that the lifespan of mice was increased with respect to a series of experiments in which the injection of venoms under the conditions of normothermia was used for $28-30$ minutes and $15-20$ minutes to $120.0 \pm 8.5$ and $160.0 \pm 19.7$ minutes, respectively. It was found that in the posthyperthermic period after a 30 -minute thermal exposure $\left(30-50^{\circ} \mathrm{C}\right)$ in the control group of animal experiments, a $100 \%$ mortality was observed during 24 hours, and with the preliminary injection of a venom in the range of doses $2-4 \mathrm{mg} / \mathrm{kg}$ Survival in $30 \%$ $50 \%$ of experimental animals was noted. Thus, the thermoprotective property of the venom of the Transcaucasian vipera has been proved.
\end{abstract}

Keywords: Venom, Macrovipera Lebetina Obtusa, Thermoprotective Property, Mices, Zootoxins

\section{Introduction}

Venomous snakes inhabit all continents of the globe except Antarctica. They are particularly abundant in tropical areas of Asia, Africa, South America and Australia. Russia and Azerbaijan [1,2,3].

Venoms of viper species are poorly characterized.

By the method of atomic absorption spectrometry, the trace element composition of venom Macrovipera lebetina obtusa, from different regions of Azerbaijan has been studied. Ions - $\mathrm{Cr}, \mathrm{Pb}, \mathrm{Cd}, \mathrm{Zn}$ was revealed in venom of snake. Radiospectrometric studies have shown that the venom samples contain radionuclides Ra $228(0.08-0.174 \mathrm{mBq} / \mathrm{g})$, Ra $226(0.35-2.48, \mathrm{mBq} / \mathrm{g}) \mathrm{K} 40(1.35-23.4 \mathrm{~Bq} / \mathrm{kg})$ and Cs 137 (MDA $=0.315$ [4].

By autors the isolated phospholipase A 2 were studied in more details and found to exert their toxins action both on lipid membranes [5] and on nicotinic acetylcholine receptor [6].

Phospholipase A 2 and nucleotide degrading enzymes were reported for the first time. Compositions of Vipera kaznakovi and Vipera orlovi venoms were described for the first time and showed the greatest similarity among the four venoms studied, which probably reflected close relationship between these species within the "kaznakovi" complex [7].

At present, the conventional view is that according to which the basic biological properties of animal venoms are determined by non-enzymatic polypeptides, along with them, powerful enzyme systems are contained in the venoms, the nature and specificity of which in most cases determine the identity of the integral picture of poisoning. From single literature data, a fundamentally new thermoprotective property of zootoxins, which the authors associate with the main polypeptides of venoms is known $[8,9,10]$.

The effect of high ambient temperature on living organisms, including on animal organisms, covers a number 
of physiological and biochemical issues. One of the such questions is the spectrum of the short-term effect of temperature on living organisms or episodic cases of overheating, which are not characteristic in conditions of vital activity and life. The organism more often faces a more or less prolonged influence of a high external temperature, which is associated with climatogeographical conditions or with specific processes $[11,12]$.

It should be noted that living organisms encounter periodically with a prolonged influence of a high external temperature, which is due to climatic conditions or to the specifics of the processes.

From literature sources it is known that the extreme temperature for mice starts from $40^{\circ} \mathrm{C}$ and above. Under conditions of experimental hyperthermia $\left(50\right.$ and $60^{\circ} \mathrm{C}$ ), zootoxins of different taxonomic groups in a certain range of doses exhibit a thermoprotective effect in one way or another. Experimental studies of domestic and foreign authors are related to the study of the picture of poisoning with zootoxins, their effect on the main functional systems under normal conditions $\left(20^{\circ} \mathrm{C}\right)$. The question of the reaction of the functional systems of the organism in conditions of an elevated temperature when infected with poisons of animals remains open $[13,14,15]$.

The aim of this work was the study of the thermoprotective properties of the poison of the Transcaucasian vipera (Macrovipera lebetina obtusa) at the level of the whole organism.

\section{Materials and Methods}

The material of the research was the venom of the Transcaucasian vipera, dried in a desiccators over sodium chloride vapor.

Experimental studies conducted on the mice with a body weight of 18 - $22 \mathrm{~g}(\mathrm{n}=120)$. All mice before the experiment were kept on the general diet of the vivarium. Solutions of samples of the venom of the vipera were prepared immediately before the experiment and were administered intraperitoneally. To investigate the dose of the dependent effect of the venom of the vipera under hyperthermia, the probit analysis was used to determine the DL 50 for the sample of the vipera venom, which was found to be 2.6 (2.0 3.2) $\mathrm{mg} / \mathrm{kg}$.

Experiments on the study of the effect of high temperatures on the lifespan of experimental mice were carried out in a thermocamera designed by us, in the form of a sealed device $1.0 \times 0.5 \times 1.0 \mathrm{~m}$ with insulated walls and ventilation holes. The experiments were carried out at temperatures of $20,30,40,50^{\circ} \mathrm{C}$. The high temperature was maintained by means of a fan heater located outside the chamber and a temperature stabilization unit, the sensor of which was located inside the chamber. In the chamber there was free access to food and water. The survival time, as well as behavioral responses of mice (activity, death pattern, etc.) was recorded at given temperature conditions. The received data were subjected to statistical processing by the Student's criterion.

\section{Results and Discussion}

Experiments on the effect of temperature in the range of 40 - $50^{\circ} \mathrm{C}$ showed that for mice not acclimatized to high temperatures, it is inadequate and leads to stress reactions, resulting in the subsequent rapid death of experimental animals as a result of excessive heat input into the body. Under these temperature conditions, white mice, on average, lived up to 35 minutes.

At the injection of the venom to the mice, a two-phase pattern was observed in the survival of experimental animals. At low doses, there was an increase in the lifetime, at higher doses, there was a decrease in the lifespan of mice compared to control.

It should be noted that in the experiments with the venom of vipera, at the first minutes of heating up to $30^{\circ} \mathrm{C}$, the initial lack of mobility, mild lethargy, which turned to "over activity" in the 15th minute (intensive search for an exit, active movement from angle to corner, aggressiveness) was noted.

At intraperitoneal injection of the venom of a vipera in a dose of $2 \mathrm{mg} / \mathrm{kg}$, an increase in the motor activity of the animals was observed on 15 minutes of thermal exposure, after 40 minutes the death of the first mouse was noted, and the last mouse died only after 60 minutes.

At a dose of $4 \mathrm{mg} / \mathrm{kg}$, high motor activity was recorded already on the 10 minute of heating.

In general, the life expectancy in the experiment was much higher than control.

At the injection of the venom (Intraperitoneal injection for mouse) of vipera a at a dose of $4 \mathrm{mg} / \mathrm{kg}$ at 12 minutes of thermal exposure, an increase in the motor activity of the animals was observed, after 50 minutes the death of the first mouse was observed, the last mouse died only after 90 minutes.

At intraperitoneal injection of the venom of vipera in a dose of $4 \mathrm{mg} / \mathrm{kg}$ and with a temperature exposure of up to $50^{\circ} \mathrm{C}$, a sharp increase in the heat resistance of animals occurred. After 1 hour after placing in a thermo camera, the mice had a "disheveled" appearance and moved crawling along the cell, clustered together. Under such a thermal regime, the life span of mice increased significantly (in comparison with the group of mice treated with the venom of vipera at a dose of $2 \mathrm{mg} / \mathrm{kg}$, they lived from $120.0 \pm 8.5$ minutes, up to $160.0 \pm 9.7$ minutes).

Thus, in a series of experiments on mice, we estimated the life span of animals exposed to thermal exposure $\left(30-50^{\circ} \mathrm{C}\right)$ for 30 minutes with the injection of the venom of vipera in doses $(2 \mathrm{mg} / \mathrm{kg}$ and $4 \mathrm{mg} / \mathrm{kg}$ ) Thermoprotective action. Thus, if all animals ( $0 \%$ of survivors) perished in the control series within 30 minutes of thermal exposure, then the effect of a high external temperature with the injection of Macrovipera lebetina obtusa venom to the experimental animal was accompanied by the survival of the majority of mice (Tables 1, 2, 3). 
Table 1. Data on the lifespan of mice with a temperature exposure of up to $30^{\circ} \mathrm{C}$ venom of vipera, $\min (M \pm m)$.

\begin{tabular}{lll}
\hline \multirow{2}{*}{ A dose of vipera venom } & \multicolumn{2}{l}{ The lifespan of mice in minutes } \\
\cline { 2 - 3 } & Control & Experience \\
\hline $2 \mathrm{mg} / \mathrm{kg}$ body weight & $28-30$ & $60.0 \pm 3.7$ \\
$4 \mathrm{mg} / \mathrm{kg}$ body weight & $15-20$ & $90.0 \pm 5.3$ \\
\hline
\end{tabular}

Table 2. Data on the lifespan of mice with a temperature exposure of up to $40^{\circ} \mathrm{C}$ venom of vipera, $\min (M \pm m)$.

\begin{tabular}{lll}
\hline \multirow{2}{*}{ A dose of vipera venom } & \multicolumn{2}{l}{ The lifespan of mice in minutes } \\
\cline { 2 - 3 } & Control & Experience \\
\hline $2 \mathrm{mg} / \mathrm{kg}$ body weight & $28-30$ & $80.0 \pm 7.9$ \\
$4 \mathrm{mg} / \mathrm{kg}$ body weight & $15-20$ & $130.0 \pm 15.3$ \\
\hline
\end{tabular}

Table 3. Data on the lifespan of mice with a temperature exposure of up to $50^{\circ} \mathrm{C}$ venom of vipera, $\min (M \pm m)$.

\begin{tabular}{lll}
\hline \multirow{2}{*}{ A dose of vipera venom } & \multicolumn{2}{l}{ The lifespan of mice in minutes } \\
\cline { 2 - 3 } & Control & Control \\
\hline $2 \mathrm{mg} / \mathrm{kg}$ body weight & $28-30$ & $120.0 \pm 8.5$ \\
$4 \mathrm{mg} / \mathrm{kg}$ body weight & $15-20$ & $160.0 \pm 19.7$ \\
\hline
\end{tabular}

From the foregoing it follows that with intraperitoneal injection to mice 2 - $4 \mathrm{mg} / \mathrm{kg}$ of the investigated samples of the venom of the vipera, with thermal exposure, the lifespan of experimental animals increases with respect to a series of experiments in which the introduction of poisons under the conditions of normothermy was used.

Our experimental studies indicate significant changes in the functioning of the organism during acute overheating. With the introduction of various doses of the venom of vipera (at $30,40,50^{\circ} \mathrm{C}$ ), the life span of experimental animals does not decrease, in contrast to cases with a temperature of $20^{\circ} \mathrm{C}$, but, on the contrary, increases.

After passing the optimal dose interval, the effectiveness of the protective action of the venom starts to decrease, and the survival rate of mice decreases compared to the control. Probably, in this case, the negative influence of toxic components increases and prevails over the increase of heat resistance, causing irreversible changes in the body. With simultaneous exposure to high temperature and venom of vipera, the maximum thermal protection effect is observed with the injection of zootoxin followed by exposure in a thermal chamber at $50^{\circ} \mathrm{C}$. The toxic effect of toxic components is enhanced and prevails over the increase in heat resistance, causing irreversible changes in the body. In this case, the life span of mice at $50^{\circ} \mathrm{C}$ is $-160 \pm 19.7 \mathrm{~min}$

Thus, as follows from the results of our investigations, vipera venom has a thermoprotective effect. In our opinion, this effect is associated with the nonspecific reaction of the mice organism to the snake venom, which acts as a stressor. With prolonged or repeated stress effects, the power of stress-limiting systems is increased and, in all probability, the stabilization of structures is formed, which manifests itself in the considerable stability of intracellular structures to unfavorable environmental influences.

An increase in the external temperature to 30,40 , and $50^{\circ} \mathrm{C}$ is accompanied by a decrease in the lifespan of experimental animals, and this value depends on the temperature load. At temperatures of 30,40 and $50^{\circ} \mathrm{C}$, the life expectancy of experimental animals increases.

From the foregoing it follows that in experiments on laboratory animals an increase in the lifespan of experimental animals was revealed with the preliminary injection of venom of vipera, in comparison with the use of only a high external temperature.

\section{Conclusions}

It has been established that with the joint use of venom of vipera and high external temperature, the maximum thermal protection effect is observed at a temperature load of up to $50^{\circ} \mathrm{C}$ was experimentally revealed that with intraperitoneal injection to mice of $2-4 \mathrm{mg} / \mathrm{kg}$ of the investigated samples of the vipera venom, with thermal exposure, the life span of experimental animals increases with respect to a series of experiments in which the injection of venom under normothermia conditions from 28 - 30 minutes and $15-20$ Minutes to $120.0 \pm 8.5$ and $160.0 \pm 19.7$ minutes, respectively.

The thermoprotective property of vipera venom was revealed. It was found that in the posthyperthermic period after a 30-minute thermal exposure $\left(30-50{ }^{\circ} \mathrm{C}\right)$, in the control group of animal experiments, a $100 \%$ mortality was observed during 24 hours, and with preliminary intraperitoneal injection of a vipera venom in a dose range of $2-4 \mathrm{mg} / \mathrm{kg}$ survival in $30 \%-50 \%$ of experimental animals was noted.

\section{References}

[1] Tuniyev, B. S., Ostrovskikh S. Two new species of vipers of "kaznakovi" complex (Ophidia, Viperinae) from the Western Caucasus. Russ. J. Herpetol. 2001, 8, 117-126.

[2] Tuniyev, S. B., Orlov, N. L.,Tuniyev, B. S., Kidov F. F. On the taxonomical status of steppe viper from foothills of the south macroslope of the East Caucasus. Russ. J. Herpetol. 2013, 20, 129-146.

[3] Abiyev H., Topchiyeva Sh. The study of the physical properties of Macrovipera lebetina obtusa venom. Journal of Basic and Applied Scientific Research. 2013, 3 (11), 373-377.

[4] Abiyev H. A., Babayev E. T., Topchiyeva Sh. A. The impact of environmental pollutants on viper venom Macrovipera lebetina obtusa. Journal of Entomology and Zoology Studies. 2016,4 (3), 378-381.

[5] Ghazaryan N. A., Ghulikyan L., Kishmiryan A., Andreeva T. V., Utkin, Y. N., Tsetlin, V. I., Lomonte B., Ayvazyan N. M. Phospholipases A 2 from Viperidae snakes: Differences in membranotropic activity between enzymatically active toxin and its inactive isoforms. Biochim. Biophys. Acta. 2015, 1848, 463-468.

[6] Vulfius, C. A., Kasheverov, I. E., Starkov, V. G., Osipov, A. V., Andreeva, T. V., Filkin, S. Y., Gorbacheva, E. V., Astashev, M. E., Tsetlin, V. I., Utkin, Y. N. Inhibition of nicotinic acetylcholine receptors, a novel facet in the pleiotropic activities of snake venom phospholipases A 2 . PLoS ONE. 2014, 9. 
[7] Sergey I. Kovalchuk, Rustam H. Ziganshin, Vladislav G. Starkov, Victor I. Tsetlin and Yuri N. Utkin. Quantitative Proteomic Analysis of Venoms from Russian Vipers of Pelias Group: Phospholipases A 2 are the Main Venom Components. Toxins. 2016, 8,105.

[8] Artishevsky A. A. Morphofunctional changes in the thyroid gland and adrenal glands in rat embryos under the influence of hyperthermia / A. A. Artishevsky, B. C. Gaiduk. 8 Congress of the Byelorussian, fiziol. Society for them. I. P. Pavlova. Tez. Doc. Minsk, 1994, 8-9.

[9] Khomutov A. E., Yagin V. V. Bulletin of the University of Nizhny Novgorod. Series Biology. N. Novgorod, 2005. , 2 (10), 152-156.

[10] Khomutov AE, Pursanov K. A., Danilova O. O. Actual problems of herpetology and toxicology. Issue. 9. Togliatti, 2006, 182-188.
[11] Khomutov AE, Pursanov K. A., Danilova O. O. Bulletin of the Nizhny Novgorod State University. N.I. Lobachevsky. Morphological changes in rat lungs under the action of heparin and zootoxins under hyperthermia. 2007, b,112-115.

[12] Khomutov AE, Lushnikova O. V. Posthyperthermal changes in rectal temperature and survival of rats against the background of the action of zootoxins. Bulletin of the Nizhny Novgorod State University. N. I. Lobachevsky, 2009, 5, 109112.

[13] http://www.labome.ru/method/Protein-Quantitation.html

[14] www.unn.ru/pages/disser/699.pdf

[15] www.nizhgma.ru/_resources/directory/371/common/luchniko va. 